\title{
Analysis and Reference of the Public Hazards Prevention Agreement Ying Wang ${ }^{1}$ \\ ${ }^{1}$ No. 99, Shang Da Road, Baoshan District, Shanghai, China \\ aYwang021@163.com
}

Keywords: Public hazards prevention agreement; Environment management; Local government; Administrative bond

\begin{abstract}
After World War II, Japan's economic development led it into the ranks of economic powers rapidly. But at the same time, Japan's pollution, environmental problems, not only to Japan's natural environment caused great damage and pollution, but also to the physical and mental health of the Japanese people caused irreversible harm. In 1964, the Yokohama Municipal Government of Japan took the lead in signing an agreement with enterprises on the prevention of public hazards, thus opening the prelude to the agreement signed by the government and enterprises after the war. After more than 30 years of practice, these public nuisance prevention agreements have effectively solved the problem of public hazards in Japan. From the current point of view, China's environmental governance management system still adopts the central government-led model, under which the enthusiasm and autonomy of local governments can't be brought into play, and the central government has a heavy burden on environmental governance. Therefore, Japan's local government plays a leading role, and the central government combined with the governance model is worth learning from China. By introducing the system of the agreement on the prevention of public hazards in Japan and analyzing its legal nature, this paper concludes that it is of great significance to introduce the system into China's current environmental management model, which mainly focuses on administrative compulsion.
\end{abstract}

\section{Introduction}

Nowadays, the global environmental problems have become the common challenges faced by all countries. The traditional management model which only relies on national power can't deal with the increasingly serious environmental problems. It is imperative to change the single and traditional management model. China's society is now in a period of rapid economic development, accompanied by environmental pollution and environmental damage, the ecological balance has suffered unprecedented damage, and China's administrative compulsion as the main feature of the environmental management system due to its inherent drawbacks, it is urgent to introduce new, flexible environmental management. Rational way to make up for its shortcomings. In this case, this paper introduces the system of the public hazards prevention agreement in Japan, focuses on its legal nature, and discusses the great significance of introducing the system into China's current environmental management model, which mainly focuses on administrative compulsion.

\section{The Background of the Public Hazards Prevention Agreement}

The so-called agreements for the prevention of environmental hazards refer to those who have polluted or ecologically destructive facilities or actors, who are in common with environmental administrative organs or local community groups at the site or the place where the act involves, in matters relating to technical norms, standards, compensation measures, community relations and the settlement of environmental disputes, etc. A written agreement, agreed and observed, [1]. In 1952, the government of Shimane Prefecture signed a memorandum with Yamanashi Pulp Co. and Daiwa Textile Co. on the issue of public hazards. However, the text signed at that time was a memorandum of understanding, not an agreement in a strict sense, and the implementation effect was not strong. In 1964, the Yokohama municipal government allowed companies entering the city's Gulf of Gen An to make artificial land promises to take measures to prevent public hazards. In December of the 
same year, Yokohama Municipal Government and Tokyo Electric Power Company signed the first "Public Hazards Prevention Agreement" in Japan, which required the latter to formulate and implement local sewage discharge standards higher than national standards, involving smoke, drainage, noise and many other aspects[2]. The model soon became the object of imitation of in all prefectures and municipalities in Japan[3]. Other heavily polluted enterprises, including power companies, must also sign pollution prevention agreements with local governments before they are allowed to invest in local plants [4]. The public hazards prevention agreement has increased rapidly because they have greatly eased the relationship between enterprises and local residents and prevented environmental pollution. In 1968, only 30 Japanese enterprises signed agreements with the government. In 1977, there were 13,000 agreements. By the end of the 1980s, the number of agreements exceeded 30,000. According to the "White Book on the Environment" published by the Japanese Environment Agency in 2000, by 1999, the Japanese local government and enterprises had signed 54379 the public hazards prevention agreement [6]. So far, the public hazards prevention agreement, which played an important role in the governance of public hazards in Japan and even in the world, came into being.

\section{Contents of the Public Hazards Prevention Agreement}

There is no doubt that the most important target of the public hazards prevention agreement is public hazards. According to the Basic Law on Pollution Countermeasures enacted by Japan in 1967, "public hazards" are "hazards related to human health or living environment caused by atmospheric pollution, water quality pollution, soil pollution, noise, vibration, land subsidence and malodor, which are accompanied by industrial and other human activities within a considerable range". In the text of the public hazards prevention agreement, the regulation of raw materials, smoke, water discharge, noise and vibration, and odor are important contents. Table 1 shows the regulatory content of the 1980 Agreement on the Prevention of Public Hazards, in which water pollution constitutes $25 \%$ of the total number of agreements. Taking 41072 pollution prevention agreements signed by Japan in 1980 as an example, there are 3694 fuel material regulations, 6539 smoke regulations, 10167 drainage regulations, 7733 noise and vibration regulations, 5467 odor regulations and 7472 other regulations [6].

Table 1 Contents of the public hazards prevention agreement

\begin{tabular}{|c|c|c|c|c|c|c|c|}
\hline $\begin{array}{c}\text { Prevent } \\
\text { objects }\end{array}$ & $\begin{array}{c}\text { Raw material } \\
\text { regulation }\end{array}$ & $\begin{array}{c}\text { Smoke } \\
\text { regulation }\end{array}$ & $\begin{array}{c}\text { Drainage } \\
\text { regulation }\end{array}$ & $\begin{array}{c}\text { Noise and } \\
\text { vibration } \\
\text { regulation }\end{array}$ & $\begin{array}{c}\text { Malodorous } \\
\text { regulation }\end{array}$ & $\begin{array}{c}\text { Other } \\
\text { regulations }\end{array}$ & Total \\
\hline $\begin{array}{c}\text { Number of } \\
\text { agreements }\end{array}$ & 3694 & 6539 & 10167 & 7733 & 5467 & 7472 & 41072 \\
\hline
\end{tabular}

\section{Implementation of the Public Hazards Prevention Agreement}

Non-compulsory acts based on the public hazards prevention agreement, the role of governance of public hazards is concentrated in two aspects. Firstly, from the government's point of view, the emergence of pollution prevention agreements fills the gap of "lack of administrative authority" in local government's pollution control; secondly, from the enterprise's point of view, pollution prevention agreements can make the activities of enterprises get the trust of local governments and local residents under the premise of ensuring that they can restrain enterprises' emission behavior. Thirdly, the non-mandatory nature of the pollution prevention agreement enables both parties to negotiate on specific schemes without violating laws and regulations, so as to achieve a win-win situation. Under the premise of ensuring the local ecological environment, the government, enterprises and residents will win the three party.

Secondly, from the perspective of enterprises, the public hazards prevention agreement has played a crucial role in dealing with public nuisance. This is mainly reflected in order to protect the 
implementation of the public hazards prevention agreement, the agreement clearly provides for the content of the agreement on violations of the punishment system. This system is freely chosen by the enterprise, when the enterprise violates the agreement to discharge public hazards, according to the system it chose at that time to punish. Such measures are beneficial not only to the implementation of the agreement, but also to the stability of the agreement. Table 2 shows the situation of enterprises being punished for violation of regulations for 1975-1980 years, [8]. This table shows that in all kinds of punishment measures, the proportion of illegal enterprises accepting suspension of production and liable for compensation punishment reached more than $30 \%$, accounting for a larger proportion of all punishment measures.

Table 2 Enforceability of the public hazards prevention agreement

\begin{tabular}{|c|c|c|c|c|c|c|}
\hline Year & 1975 年 & 1976 年 & 1977 年 & 1978 年 & 1979 年 & 1980 年 \\
\hline $\begin{array}{c}\text { Stop production and compensate } \\
\text { for the loss system }\end{array}$ & 2808 & 3940 & 5113 & 6010 & 6290 & 6598 \\
\hline $\begin{array}{c}\text { Compensation system for } \\
\text { damages caused by unconscious } \\
\text { accidents }\end{array}$ & 510 & 895 & 1135 & 1333 & 1530 & 1738 \\
\hline $\begin{array}{c}\text { Entry into the investigation } \\
\text { system }\end{array}$ & 6062 & 7170 & 8508 & 9532 & 10545 & 11280 \\
\hline Sanctions system & 1985 & 2516 & 3244 & 3537 & 3884 & 4230 \\
\hline
\end{tabular}

\section{The Reference System of the Public Hazards Prevention Agreement for China}

China is now in such a historical period: "in the past five years, the economic strength has reached a new stage. GDP increased from 54 trillion yuan to 82 trillion and 700 billion yuan, an average annual growth rate of $7.1 \%$. The revenue increased from 11 trillion and 700 billion yuan to 17 trillion and 300 billion yuan. The ecological environment has gradually improved. We formulated and implemented three 'ten' prevention and control measures for air, water and soil pollution and achieved solid results. Energy consumption and water consumption per unit GDP have dropped by more than 20 percent, the discharge of major pollutants has continued to decline, the number of days of heavy pollution in key cities has been reduced by half, the forest area has increased by 163 million mu, and the area of desertified land has been reduced by nearly 2000 square kilometers annually. The green development has shown a gratifying situation" [9]. It can be seen that the Chinese government wishes to give consideration to environmental protection while developing its economy, and will not follow the old road of "polluting first and treating later" in the industrial age in developed capital countries [10].

China's environmental legal system started late, the environmental management system is immature and imperfect, the environmental management model is basically a model of administrative compulsion, the state through the formulation of mandatory rules for the relative set must meet the environmental standards and must perform the act or omission obligations, the relative must abide by, otherwise they will bear legal responsibility. This model has played an important role in China's environmental management system, but there are also many drawbacks: first, high management costs, difficult implementation, it is difficult to find and solve a large number of small and scattered sources of pollution; second, rigid administration, lack of enthusiasm and flexibility of law enforcement personnel, coupled with institutional problems and quality problems, efficiency. Third, the managers and the managed lack information exchange, will coordination, mutual distrust, fierce confrontation, environmental protection has no intrinsic motivation [11].

Because of its flexible regulation, the public hazards prevention agreement has been introduced 
into the current administrative compulsory mechanism, which can make up for the defects of the system itself and further improve the environmental management model in China. The implementation of the public hazards prevention agreement can ease the tension between the government and the administrative counterpart, and also establish a communication platform between enterprises and local residents. Residents can supervise the behavior of enterprises and possible government dereliction of duty in the process of negotiation of the public hazards prevention agreement through the establishment of public participation mechanism. Or omission, the introduction of this principle is conducive to the establishment of a harmonious society[12].

\section{Reference}

[1] Taiwan research foundation: Environmental Protection and Industrial Policy(Avant-garde Press, Taipei 1994), p.118. (In Chinese)

[2] M. Narumi: Yokohama way of public nuisance prevention agreements, p.279. (In Chinese)

[3] M. Wu: Journal of Xinxiang University (Social Science Edition), Vol. 24 (2010) No.1, p.56. (In Chinese)

[4] L.P. Song: On Environmental Administrative Contract System (MS., Northeast Forestry University, China 2004), p.1. (In Chinese)

[5] Y. He, B.L. Peng: Environmental Protection, Vol. 46 (2018) No.9, p.75. (In Chinese)

[6] C. Li: Environmental Protection and Circular Economy, ( 2013) No.7, p.19. (In Chinese)

[7] C. Li: Journal of China Environmental Management Cadres College, Vol. 23 (2013) No.5, p.8. (In Chinese)

[8] Wuligitu: Management Review, (2008) No.5, p.58. (In Chinese)

[9] Information on http://www.gov.cn/zhuanti/2018lh/2018zfgzbg/zfgzbg.htm

[10] L. Li: Chinese Society of Environmental Sciences (2006). (In Chinese)

[11] L. Li: Japan's Environmental Pollution Prevention Agreement System Research and its Reference,(MS., China University of Political Science and Law, China 2007) (In Chinese)

[12] T. Sheng, F.Y. Liang: World Environment, (2013) No.2, p.42. (In Chinese) 